\title{
Critiques of Popular Cultural Representations of 9/11
}

\section{Marita Gronnvoll}
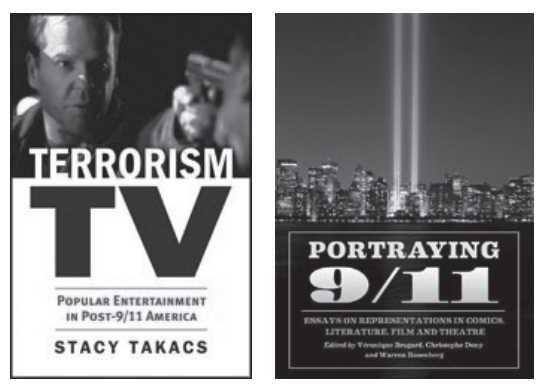

TERRORISM TV: Popular Entertainment in Post-9/11 America. By Stacy Takacs. Lawrence: University Press of Kansas. 2012.

PORTRAYING 9/11: Essays on Representations in Comics, Literature, Film and Theatre. Edited by Véronique Bragard, Christophe Dony, and Warren Rosenberg. Jefferson, NC: MacFarland. 2011.

It should come as no surprise to critics and consumers of popular culture that the attacks of September 11, 2001, were, in many ways, a media event. While a few thousand trapped in planes and smoking buildings experienced the attacks firsthand, and millions of New Yorkers witnessed the events from their city streets, billions more know of the events only through screens of various sizes, and through the page. Since that time, public figures and public intellectuals have engaged in an interpretive tug-o-war to define, or not define, this starkly emotional event, which has come to be encapsulated in the ideographic moniker "9/11." Cultural critics as diverse as Bill Maher and Susan Sontag paid the price early on for daring to posit "unacceptable" viewpoints, while seemingly the 
vast majority of mediated information conformed to political and public sentiments that decontextualized the attacks, classifying them as unprovoked "evil." What has been written in the past decade, either representing the events of 9/11 or critiquing those representations, could fill several libraries. For this essay, I will examine two books, recently published, that give scholarly treatment to representations of $9 / 11$.

The books reviewed for this essay have in common that they take popular culture seriously as a barometer for public attitudes, and do not get caught up in critical nihilism where they see popular culture as only repressive or progressive. Where they differ is that one focuses its rich, theoretical mining on television as a potential vehicle for shoring up hegemonic ideologies, while it simultaneously opens avenues for critique of those ideologies. The other aims for breadth as opposed to depth (not that its approach should be considered shallow) as it scrutinizes other forms of popular culture: namely, comics, literature, film, and performance.

In the introduction to Stacy Takacs' impressively researched book, Terrorism TV: Popular Entertainment in Post-9/11 America, the author states her position in contrast to those who would view media as a part of a vast conspiracy to control the masses:

While there is clearly a political-economic convergence of interest between Hollywood and Washington, however, the recourse to conspiracy to explain this convergence oversimplifies very complex processes of social control and implies the public plays no role in the formation, maintenance or alteration of power relations. The biggest flaw in this conspiracy theory is its assumption that military-media coproductions always achieve the desired ideological effect—support for the United States and its military. (17)

Throughout her book, Takacs demonstrates the ways in which popular television post-9/11 swung from jingoistic programming that primed the public to accept draconian policies from the Bush administration to a proliferation of programming that critiqued the administration and its hawkish war record. This shift suggests that public attitudes, and the relentless profit motive for commercial television, played at least as important a role in programming themes as did administration spin.

As Takacs resists easy classifications of "news" programming vs. "entertainment" programming, the chapters often include analysis of both, side by side. As she notes in the introduction, "Rather than reimpose some false distinction between information and entertainment, nonfictional and fictional programming, my approach is to treat all program types as simultaneously entertaining and informative" (20). The result is a fascinating and persuasive analysis of militain- 
ment, and the subsequent resistance to militainment, as the years placed psychic distance between public attitudes and the event we refer to as " $9 / 11$."

In chapter one, "9/11 and the Trauma Frame," Takacs scrutinizes news reporting on the event and discusses the ways in which news media participated in creating what Giorgio Agamben has referred to as a permanent "state of exception." She argues,

\begin{abstract}
The news media's construction of 9/11 as an "exceptional" experience of unprecedented "dimensions" ripped the events from their historical context and permitted an interpretation of them in cosmic terms. A struggle between real world political foes became, instead, a struggle between abstract good and abstract evil for the soul of humanity. (36)
\end{abstract}

This framing is in keeping with characteristics of news that journalism critic $\mathrm{W}$. Lance Bennett has elsewhere outlined, namely, that news is fragmentedincluding only the latest news detached from its context-and that news is dramatized, or reduced to melodramatic, recognizable elements of heroes and villains, good and evil. ${ }^{2}$ Takacs posits that this framing played an important role in shoring up favorable public attitudes toward the Bush administration and in shaping the notion that a completely innocent nation had been attacked on September 11,2001. Takacs goes on to demonstrate how fictional programming enhanced news reporting to create a rather distorted view of American exceptionalism: "By restaging the melodrama of American innocence first mobilized in 9/11 news coverage, Third Watch, America's Most Wanted, and The West Wing all helped prime the U.S. public to support a war on terrorism" (52). All three programs essentially upheld the Bush administration talking points of American innocence and the unprovoked evil actions of the terrorists helping to create, as Takacs notes, a "climate of fear" that made extreme Bush administration tactics seem reasonable (53).

In the chapter "Spy Thrillers and the Politics of Fear," Takacs shifts her focus to the plethora of programming that portrayed government agencies engaged in fighting a covert war on terrorism. These programs ranged in popularity and longevity from the short-lived The Agency and Threat Matrix, to the hugely popular and long-running 24 . According to Takacs, what these programs have in common is that the way they "constructed their terrorist villains and patriotic heroes helped normalize the state of emergency and promote the acceptance of policies of surveillance, detention, interrogation, and interdiction that were fundamentally antidemocratic" (64). The construction of a perpetual "state of emergency" created not only an atmosphere where a "good" citizen relinquishes rights in the name of national security, but where heroes take extreme action, such as torture, as part of their duty in protecting American interests. Even Supreme Court Justice Antonin Scalia is noted by the national press to have publicly excused the actions of 24 character Jack Bauer, who routinely performs torture as 
part of his heroic framing. With regard to the fictional government agent's torture tactics, Scalia commented: "Jack Bauer saved Los Angeles ... he saved hundreds of thousands of lives.... Is any jury going to convict Jack Bauer? I don't think so." ${ }^{\prime 3}$ If a Supreme Court justice proposes that certain actions are above the law in a state of emergency, is it any wonder, as Takacs' analysis suggests, that the average American would come to believe the same?

Shifting from scripted dramas, in "Reality Militainment and the Virtual Citizen-Soldier" Takacs draws upon the scholarship of communication scholar Roger Stahl, among others, to take a look at "docusoaps," or reality-based programs where soldiers in active duty are filmed to give the public an inside look at their daily lives. Takacs explains,

The people at the center of these [docusoaps] are presented as representatives of a larger social order, but the goal of docusoaps is not to interrogate, explain, or alter the social order as a documentary might. Rather, it is to create "a spectacle of the everyday that emphasizes its participants' performance of identity." $(105)^{4}$

These programs serve the purpose of representing soldiers as everyday, trustworthy "guys-next-door," who we can trust that their "use of force will be measured, precise, and discriminate, rather than gratuitous" (107). These programs were often produced with the explicit consent of Bush administration officials. As Takacs notes,

While journalists were systematically denied military assistance and access to the troops, Secretary of Defense Donald Rumsfeld personally signed off on the plan to let the producers of [Profiles from the Front Line] "[troop] around all over the countryside - flying on planes, going on ships, going on patrol with the $101^{\text {st }}$ Airborne, [and] living a rugged life." (110)

It is no wonder that the administration would sign off on such docusoaps as Takacs' analysis shows they reiterated the false justification for the Iraq War by repeatedly making connection between Saddam Hussein and the attacks of 9/11.

"Fictional Militainment and the Justification of War" is an analysis of the popular military-themed program $J A G$. Here Takacs argues that the program attempted to remediate the past, thus making a move to actively reshape public memory with regard to U.S. actions in the war on terrorism. In at least one case, the producers of the program were given access to the Bush administration's unreleased policy of using military tribunals to prosecute suspected terrorists. An episode of the program was thus produced, before any public debate was allowed to develop, the narrative of which demonstrated that military tribunals were the only way to prosecute detainees. Takacs points out: 
Thus, by coproducing the "Tribunal" episode of $J A G$, the Bush administration sought to intervene in and shift the ground of public debate about the treatment of prisoners before the courts could rule on the subject. It was the ultimate act of cultural preemption. (129)

So while militainment is nothing new, and $J A G$ is in many ways a retread of past programs that glorify the military, Takacs notes: "What is new, however, is the series' self-conscious intention to intervene in the formation of the cultural memory of the wars in Afghanistan and Iraq as they are happening" (140, emphasis in original).

In "From Virtual Citizen-Soldier to Imperial Grunt," Takacs explores the ways in which, as public approval of the Iraq War decreased, military entertainment programming shifted to the glorification of the "grunt" on the ground, while often explicitly critiquing the out-of-touch politicians who put "him" there. Despite the increased critique of the war itself, war in general in these programs is still held to be a valid and necessary political tool, as well as serving the function of building character and enhancing masculinity. Takacs' analysis of the programs Over There (2006) and Generation Kill (2008) argues that they
... portray war as a showdown between the forces of civiliza- tion and savagery, with the survival of the human race at stake. This simplified morality tale is familiar to U.S. viewers from frontier narratives gone by and does little to provide insight on the specific war in Iraq. (149)

This chapter aptly demonstrates that the glorification of the military in television programming need not come as a direct result of Bush administration intervention. Rather, the commercial aspect of programming provides all the justification needed for such ideologies to be packaged and sold to the American public. The programs demonstrate that even when public support for a particular military action is lacking, the military itself is considered to be above reproach.

With "Contesting the Politics of Fear," Takacs' analysis shifts to programs that actively criticized the Bush Administration's ongoing wars. This chapter demonstrates how television programming can be used as a tool of resistance and not simply as a hammer for hegemonic principals. Once again, Takacs combines genres, resisting problematic classifications, examining programs such as The Daily Show With Jon Stewart, the short-lived comedy Whoopi, and the critically acclaimed comedy Arrested Development. The second half of the chapter is a careful scrutiny of a bevy of science fiction programs where American tactics in the war on terrorism are critiqued through analogy. One function served by programs such as The Daily Show, Whoopi, and Arrested Development was to provide a self-reflexive critique "of the media's role in the impoverishment of political discourse ... their collective use of humor for political ends did much 
to reinvigorate a climate of public debate stifled by tragedy and political paralysis on the left" (174). The science fiction programs, on the other hand-among them, Jericho and Lost - "sought to push the logics of fear and paranoia to their limits in order to deconstruct the dynamics of securitization that followed from the use of fear as a political stimulate post-9/11" (176). Despite these programs often bald critique of American policy, commercial advertising still provides the motivation for the entertainment industry to apply the brakes. In the case of the programs under consideration in this chapter, the critique, even if pointed, was confined the relatively safe arena of comedy and the fantasy of science fiction.

Takacs expands her scrutiny of resistance in television programming in "The Body of War and the Collapse of Memory," this time by contrasting programs that personalize and depoliticize war with those that do not. Takacs examines programs such as talk show The Montel Williams Show and reality show Extreme Makeover: Home Edition, both of which included programming that tended to focus on the pain of soldiers, and encouraged audiences to channel their anger away from political action and toward consumerist responses (e.g., giving a soldier's home a makeover to heal his pain). Takacs sees two problems with such melodramatic portrayals: "One, they end up depicting U.S. soldiers as the true victims of U.S. military aggression ... Two, this exclusive emotional identification is presented as the only viable response to the historical trauma of war" (221). In contrast to these programs, Takacs takes a look at television series that deconstructed "acceptable" responses to the war. These programs, chiefly the network drama ER and the premium cable series Six Feet Under, "encourage viewers to linger with uncertainty, analyze it and work through its ramifications more deliberately, thereby eliciting a more active mode of historical witnessing" (223). These programs provide no easy, melodramatic, or consumerist solutions to war trauma. Rather, they use their sophisticated narratives to "open up questions about the conduct, costs, and consequences of imperial warfare" (235).

"Trauma and Memory Ten Years Later," the book's epilogue, effectively brings home Takacs' central theme, namely, that if television played a role in shaping public opinion in support of Bush administration policies, however extreme and draconian they proved to be, it also played a role in providing a space for critique of those same policies. In other words, television cannot be dismissed as simply the "tool of the establishment." As Takacs puts it in a nice summary of the book's themes,

By recording, transcribing, and even transcoding reality, media make it possible for subjects to bear witness to history themselves, to process and reprocess the "material of the witnessed world" in a provisional structure. This is not to say that TV functions as a neutral conduit of information about the real or that it conveys Truth with a capital T; rather, like memory itself, television is riddled with errors, blind alleys, and defensive 
blockages; it is structured by delay and discontinuity; and it contains inaccurate, misleading, and partial information. (244)

Critics of television, media, or popular culture - from any disciplinary field — will not be disappointed with Takacs' book. It is extremely well researched, theoretically sound, accessible to students and academics alike, and has much crossover appeal to those interested in public scholarship. Takacs makes no simplistic causal claims, and her serious treatment of perhaps the single most influential medium (so far) in human history is fascinating and refreshing.

The second book I review for this essay is quite different from Takacs' in both approach and format, yet there are some important similarities that make them excellent companion pieces for the critic of popular culture. Like Terrorism TV, the anthology Portraying 9/11: Essays on Representations in Comics, Literature, Film and Theatre is concerned with the ways in which popular culture shapes public perception and memory of the events that took place on September 11, 2001. But where Terrorism TV focused exclusively on the shaping powers of television, Portraying $9 / 11$ focuses on other popular culture media and excludes television entirely from critical consideration. Like Terrorism $T V$, the editors of Portraying 9/11 note in their introduction the role of media in the immediate aftermath of 9/11: “... media pundits and government officials quickly attempted to commemorate the events within recognizable conventions, relying on notions such as heroism, nationalism, and patriotism" (3). And while subjecting the notion of the exceptional nature of 9/11 to critical scrutiny, the editors and contributors of the anthology do not deconstruct the event to the point of dismissing it, as some postmodern writers arguably have done. Instead, the focus of this book is the examination of $9 / 11$ as a legitimately traumatic event, involving real human beings, and how media provided both an outlet for mourning loss and critiquing response. As the editors further note: "The essays in this volume thus constantly remind us that memory oscillates between remembering and forgetting and is therefore subject to assimilation, appropriation, and even distortion" (5).

The anthology contains eleven short chapters, each contributed by a different author, most of whom hail from English Literature. The book is also helpfully divided into three parts: Comics, Literature, and Performance. The individual chapters stand alone nicely, offering easy reference for researchers on the hunt for source material. In part one, "Comics," one chapter examines the artwork on several covers of the New Yorker in the months following 9/11, and two chapters take a look at popular superhero comics for their analogous treatment of the events of 9/11 and the United States' response. In chapter one, "Covering 9/11: The New Yorker, Trauma Kitsch, and Popular Memory," Timothy Krause'scareful reading of the New Yorker covers concludes that while "they inevitably deconstruct themselves and offer up - in fact, invite - politicized readings that are more complex and more disturbing" (14), they also tended to "posit their readers, not as active participants in the tragedy and memorialization of $9 / 11$, but as passive consumers of the events" (16). In chapter two, "Spandex Agonistes: Superhero Comics 
Confront the War on Terror," Matthew J. Costello argues that, unlike some forms of media that unreflexively accepted the prevailing, simplistic, Manichean frame posited by the Bush administration, superhero comics did not. Instead, according to Costello, superhero comics contested this frame in two ways: "First, the attacks are not characterized as a blameless massacre of innocents by savages ..." and second, they portray "the American response not as a morally righteous act, but as the product of national hubris" (31). Stephan Packard, author of chapter three, “'Whose Side Are You On?' The Allegorization of 9/11 in Marvel's Civil War," supports Costello's conclusions. Packard examines the Civil War series, in which Marvel's superheroes are turned against each other in a war where one side represents law and order and the other represents resistance to questionable methods in use by the government to achieve its goals of protecting citizens. This unconventional use of superheroes, many of whom readers and fans might consider to be unquestioning supporters of the American national ethos, provides a powerful allegory of the problematic nature of framing the war on terrorism in terms of good and evil.

Part two, "Literature," includes four chapters that analyze popular fiction for its response to and construction of the events of 9/11. In chapter four, "September 11 and Cold War Nostalgia," Aaron Derosa analyzes several works of fiction, including Don DeLillo's Falling Man and Jonathan Safran Foer's Extremely Loud and Incredibly Close, and suggests that the American public has come to see $9 / 11$ in terms of a nuclear conflict. He notes,

The narrative built around 9/11 historicized the event through, among other things, its atomic imagery that promoted the reestablishment of Cold War culture, a culture whose beliefs and behaviors arose from the socio-cultural construction of a monolithic binary of "good" versus "evil" where the latter threatened the cultural annihilation of the former, either by means of nuclear holocaust, cultural and political insurgency, or both. (64)

A second consideration of DeLillo's novel comes in chapter five, "Don DeLillo's Falling Man: Countering Post-9/11 Narratives of Heroic Masculinity," authored by Magali Cornier Michael. Cornier Michael argues that Falling Man deconstructs several different binaries in its pages. On the one hand, rather than blithely accepting the simplistic "good America vs. evil terrorist" narrative, Falling Man "forces its readers to grapple with the ways in which Americans have been complicit with vast, complex, and arguably unjust global economic systems that cannot be totally divorced from the horrific events of 9/11" (77). A second binary Cornier Michael examines is a gender binary. While others have forcefully and persuasively argued that post-9/11 culture reified and enforced notions of rugged masculinity and victimized femininity, Falling Man "seems to suggest that the times require the forging of new kinds of relationships that 
move beyond outmoded, binary conceptions of masculinity and femininity and of the domestic and public realms" (85). ${ }^{5}$ In "Misplaced Anxieties: Violence and Trauma in Ian McEwan's Saturday," Ulrike Tancke examines a novel where the events of 9/11 remain on the periphery, but nonetheless operate allegorically throughout. McEwan's treatment of violence questions "the legitimacy of the interpretive venture which elevates $9 / 11$ to the level of a universal turning point" (92). This is not to suggest that Jean Baudrillard's deconstruction of 9/11 as a mere "simulacrum" is a more useful interpretation of the event. ${ }^{6}$ Rather, as Tancke notes,

The cultural preoccupation with $9 / 11$ and its allegedly traumatizing effects is a prime example of how we tend to turn our lives - and history more generally - into narrative, into a convincing story boasting turning points and life-changing events. (100)

This interpretive struggle is evidenced in chapter seven, the last chapter of this section. In "The Mediated Trauma of September 11, 2001, in William Gibson's Pattern Recognition and David Foster Wallace's 'The Suffering Channel," Marc Oxoby takes on the Baudrillardian view of 9/11 as simulacrum, and refutes it. He argues, instead, that even if most of the world did not view the event firsthand, that does not mean that the mediated experience — even the fictionalized experience-was less authentic. Rather, through his reading of several works of fiction that allegorize 9/11, Oxoby argues for the value of fiction and language "to offer a deeper understanding of $9 / 11$ " (103), because it "deals not just in purely rational thought, but gives itself over to emotional responses" (116).

Part three, "Performance," includes analyses of film and stage plays. In the chapter "Terror and Mismemory: Resignifying September 11 in World Trade Center and United 93," Gerry Canavan takes up the now familiar theme of the role of popular culture in creating a permanent state of emergency. Canavan takes issue, as do a number of other cultural critics, with the sanitization of 9/11 as an attack without bodies. From the lack of published photos or news coverage of 9/11 "jumpers" to popular film that avoided displaying death, popular culture played a role in making the attack "unreal, and thus unthreatening" (124). As Canavan notes, "If, in World Trade Center, no one died on 9/11, in United 93 we all did," but, in keeping with the trend, the audience is not allowed to see it (129). Superheroes are given treatment again in chapter nine, but this time in film, and they display far less resistance to the "party line" than was the case in comics. In "From Flying Man to Falling Man: 9/11 Discourse in Superman Returns and Batman Begins," Dan Hassler-Forest examines two blockbuster superhero films that nostalgically reify post-9/11 notions of heroism and victimization without including the event itself as part of the narrative. What HasslerForest concludes is that "although these films demonstrate the wistful desire to resurrect our most familiar popular icons, they also show us that we will not be 
able to rely on superheroes to save the world in the $21^{\text {st }}$ century" (145). The film United 93 is taken up again in chapter ten, "Authenticating the Reel: Realism, Simulation, and Trauma in United 93," but this time with a more generous approach. Author Frances Pheasant-Kelly examines "realism and realist aesthetics in United 93," arguing that "the film deviates from the predictable patterning of more conventional Hollywood cinema and how representation intersects with reality, blurring the boundary between them" (149). Pheasant-Kelly describes the film as determinedly avoiding being overly dramatic and, instead, striving for realism. Indeed, as no one knows what actually happened on the flight, the film's realist aesthetics collapse the boundary between reality and fiction, in many ways making the film more "real" than news reports of the plane's crash. Thus, "the recontextualization of these images within the narrative of United 93 as simulation resurrects some of the original trauma in its close approximation to the real" (155). The final chapter in this section, "Connecting in the Aftermath: Trauma, Performance, and Catharsis in the Plays of Anne Nelson," by James M. Cherry, shifts the focus from film to stage plays. Cherry's arguments here are similar to those made by some of the authors in the literature section, namely, that language can aid audiences in working through trauma. Anne Nelson's stage play, The Guys, which was fast-tracked into theaters within a few months of 9/11, explicitly takes on the theme of using language to work through trauma with its protagonist helping a firefighter construct a eulogy for his fallen comrades. Through incorporating the audience in some innovative ways, Anne Nelson's works "instantiate that it is through connection and exchange, through people and cultures and nations 'jumping tracks,' that trauma can be addressed. They articulate how in the aftermath of trauma, grief and opportunity always coexist" (171).

Thematically, Portraying 9/11 is concerned with collective grappling with national trauma. However, it is to its credit that none of the contributors reduce this wrestling to collective therapy. Instead, the critiques remain focused on the representations of trauma, grief, and identity making as politically charged processes. If there is one critique I would offer it is that the book ignores that ever powerful mode of public expression: television. By focusing on mostly high-culture texts, the book feels incomplete. Yes, there are multiple books that do consider the importance of television in creating and maintaining American identity post-9/11 —including Terrorism $T V$ - but when an anthology purports to examine representations in popular culture and ignores television, that is problematic. It should not, however, discourage those who wish to engage a work that explores a broad range of popular culture texts, even if the short chapters do not allow the authors to go much in depth with their respective topics.

What both of these books accomplish is to pay homage to the awful events that took place that Tuesday morning over a decade ago, without succumbing to the emotionalism that arguably contributed to the hyperbolic national response. Additionally, they demonstrate that popular culture can be a mirror and a vehicle of national healing and meaning making. We don't just engage popular culture 
to be entertained; we engage it to understand our experiences and ourselves. For these reasons, among others, popular culture artifacts deserve the scholarly attention they have been given in these books. The authors collectively respect purveyors and consumers of popular culture as not mindless drones of the system, but rather, at times, using representations to offer sophisticated critiques of national policies. It is easy, and rather intellectually lazy, to read popular culture as only a vapid wasteland and only supporting hegemonic ideals. The scholars here avoid this trap. For that reason alone, those who study and consume popular culture will appreciate these additions to their library. For those in any disciplinary field who, at times, feel as though they search in vain for complexity in the scholarly treatment of popular culture, both of these books are reason for celebration.

\section{Notes}

1. Giorgio Agamben, State of Exception (Chicago: University of Chicago Press, 2005).

2. W. Lance Bennett, News: The Politics of Illusion, $9^{\text {th }}$ edition (New York: Pearson, 2011).

3. "Scalia and Torture," The Atlantic. June 19, 2007. Retrieved from: http://www.theatlantic. com/daily-dish/archive/2007/06/scalia-and-torture/227548/. 2009).

4. Roger Stahl, Militainment, Inc.: War, Media, and Popular Culture (New York: Routledge,

5. See, for example, Susan Faludi, The Terror Dream: Myth and Misogyny in an Insecure America (New York: Picador, 2007).

6. Jean Baudrillard, The Spirit of Terrorism (London: Verso, 2003). 